\title{
PARAMETRIC STUDY OF MARINE STEAM TURBINE PLANTS
}

\author{
M.Mosleh 1, Adel Banawan 2, Wael M. El-Maghlany 3, Ahmed G. Mohamed 4 \\ 1,2 Faculty of Engineering , Alexandria university \\ 3 Faculty of Engineering in Ismailia, Suez Canal University \\ 4 Arab academy for since, technology and maritime transport \\ Emails:momosleh@hotmail.com; abanawan@yahoo.com;ans_shehab@yahoo.com \& \\ engahmedgomaa.12@Gmail.com
}

\begin{abstract}
The steam turbine power plant has until recently been the first choice for very large power main propulsion units. Its advantages of little or no vibration, low weight, minimal space requirements and low maintenance costs are considerable. Furthermore a turbine can be provided for any power rating likely to be required for marine propulsion [1].

This research deals with the parametric study of marine steam power plants. It studies the effect of the ambient temperature which is considered as the cooling water inlet to the condenser (from $24 \mathrm{oC}$ to $35 \mathrm{oC}$ ) also the boiler pressure (from 30 bar to $60 \mathrm{bar}$ ) on the performance of the steam power plants in both fully loaded ship and ballast conditions. The performance of the power plant concerned with the thermal efficiency, the fuel consumption, the steam mass flow rate, and the mass flow rate of cooling water inlet to condenser. The procedures have been carried out for METHANE KAREELIN as LNG carrier with steam power plant rated for $29 \mathrm{MW}$.

The results showed that, the sailing in cold weather is more favorable for high thermal efficiency, less fuel and steam consumption, also less mass flow of the cooling water inlet to the condenser. Also, it is better to work under high steam pressure for high thermal efficiency, less fuel and steam consumption, and less mass flow of the cooling water inlet to the condenser. But, this pressure is limited to the metallurgy of metals that are bear this pressure as well as not based on the designer. Finally, carrying more cargo increases both the fuel consumption and steam consumption, to keep the ship speed constant as well as possible.

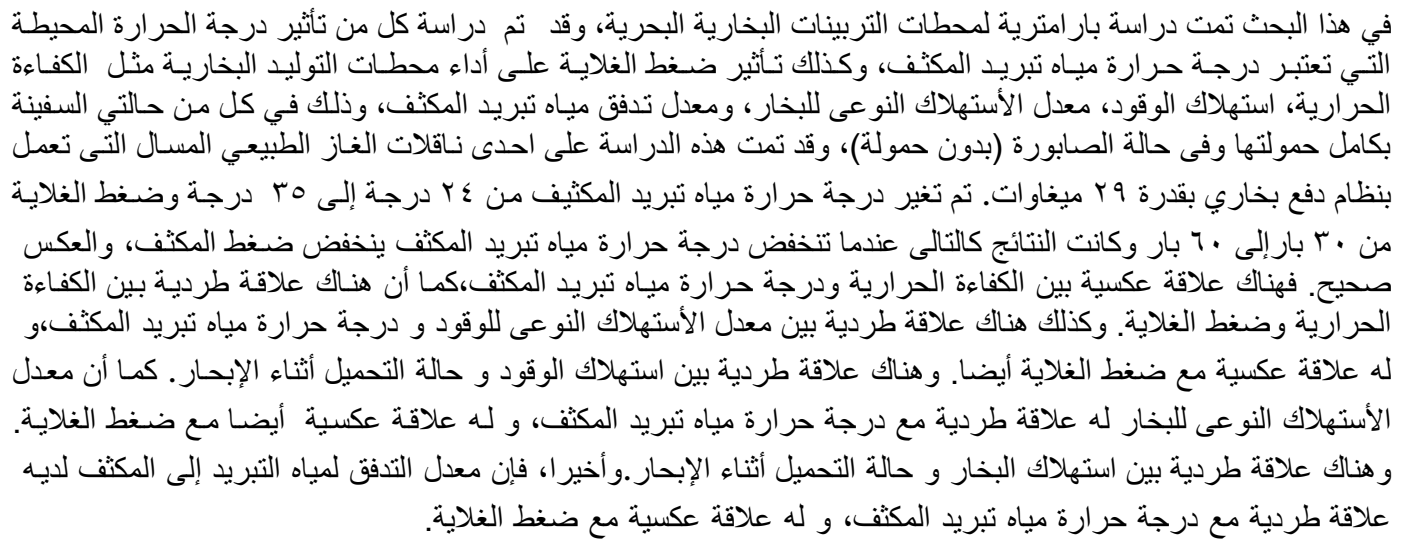

Keywords: Steam turbine; LNG carrier; propulsion system; Boiler pressure; Condenser pressure; Specific fuel consumption 


\section{INTRODUCTION}

History of marine shipments of LNG began in the late 1950s. The first commercial trades started in the early 1960s and by the 1970s international trades had been established with the subsequent requirement for LNG carriers. The LNG trade has been fairly stable in this period, characterized by long term supply contracts. [2] Reports the world fleet of LNG ships as 146 , and about half of these are 20 years old. Steam turbine plant has so many records as marine propulsion system and it is sufficiently attractive even at present because of maintenance - free and low NOx Emission for the environment. [3]

New demands in LNG shipping industry and increasing concern about environmental protection are supposed to lead the trend toward an alternative propulsion application for LNG carriers other than steam turbine, which had dominated propulsion power generators onboard the vessels for decades. The steam turbine has surely performed high reliability for a long time since it was installed on LNG carriers, except for just a few problems with high-speed reduction gearing part. It has been considered as well-proven, reliable and infrequent low-cost maintenance machinery. However the drawback is mainly in its efficiency [4]. The maximum total plant efficiency of the steam propulsion system is approximately $30 \%$ at full load and the efficiency becomes lower as the turbine load goes down. Until a few years ago, steam turbines were used for almost all LNG carriers for the propulsion plant because of their operation profitability, reliability, operability, maintainability and initial investment. Another reason is that the steam turbine plant could safely treat boil-off gas (BOG) generated from the cargo tank and could also use heavy oil as fuel. In order to enhance plant efficiency of steam turbine propulsion system, the newly developed concept has been introduced in the market, so called as Ultra Steam Turbine (UST) it used instead of Conventional Steam Turbine (CST). In (CST) the steam flow from boiler to high pressure steam turbine, low pressure turbine final to condenser and the steam flow in (UST) is from boiler to high pressure turbine to reheater, intermediate pressure turbine, and low pressure turbine final to condenser [5].

As the capacity of LNG carriers are getting bigger and they require more power, it seems that the application of steam turbine shall be carefully considered in case of very large LNG carriers due to the limitation in its output power and engine room space [6].

The purpose of heat balance is to set forth data and practices for marine steam power plant heat balance calculations and diagrams. This research is specifically applicable to oil fired but with suitable modifications it can be used for other service rating, other type of fuels, prime movers and auxiliary equipment. A heat balance is a necessary tool on the design of a marine power plant. Once the shaft horsepower, steam conditions and basic cycle have been established, a heat balance calculation can be made. From it, the various steam, exhaust, feed and condensate flows can be determined and used in selecting suitable machinery and equipment. Heat balance may also be prepared to determine optimum steam conditions and cycle design or to analyze the performance of a power plant on trials or in service [7].

\section{PROPULSION SYSTEM CONFIGURATION}

The propulsion system of METHANE KARE-ELIN

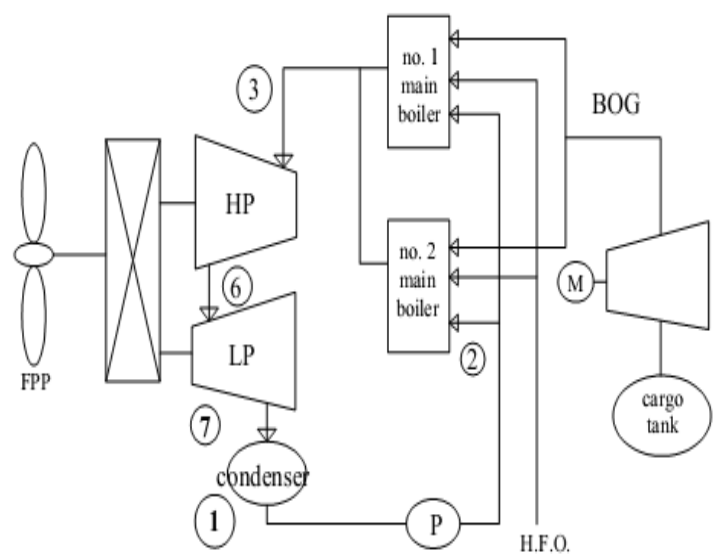

is steam plant shown in Figure (1), and figure (2) show the T-S diagram of steam propulsion system.

Figure (1) Propulsion System Configuration

The propulsion system consists of:

- boiler to generate steam to the cycle the boilers which used is KAWASAKI UME $67 / 51$ with steam condition at superheater outlet of $62 \mathrm{Kg} / \mathrm{cm} 2$ and $515{ }^{\circ} \mathrm{C}$, feed water temperature at inlet economizer $138{ }^{\circ} \mathrm{C}$, maximum evaporation $67000 \mathrm{Kg} / \mathrm{h}$ and normal evaporation $51000 \mathrm{Kg} / \mathrm{h}$ [8].

- Steam turbine to give the useful power to the propeller, the steam turbine which used is Kawasaki UA-400 its properties are output range $26500-29400 \mathrm{~kW}$ with total weight 305 ton [9].

- Condenser vacuum $722 \mathrm{mmHG}$ at $24{ }^{\circ} \mathrm{C}$ sea water gearbox to reduce the turbine speed to $90 \mathrm{rpm}$ with fixed pitch propeller (FPP) [10]. 


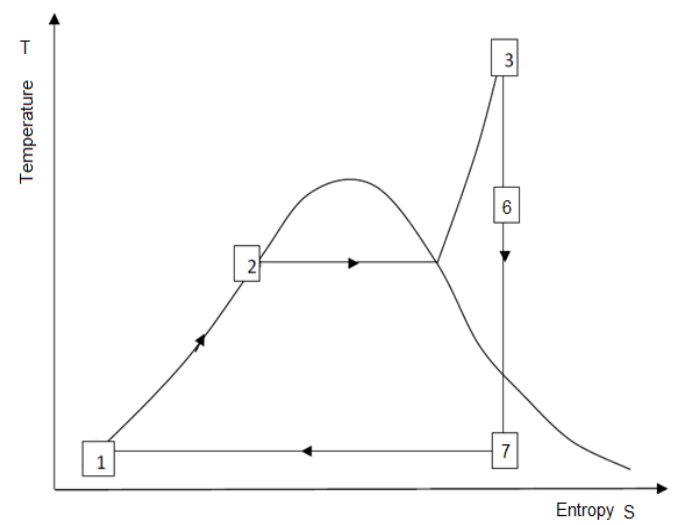

Figure (2) T-S Diagram for Steam Propulsion System

\section{Case Study Data Reduction}

Before to study the effect of changing parameters (the boiler pressure and the cooling water temperature inlet to condenser) on the performance of steam propulsion system (studies parameters). It is required to calculate the ship powering at every case of loading during sailing, first calculate the ship resistance then the powering calculation, from equations (1) to (9) [11, 12 1ND 13].

$\mathrm{R}_{\mathrm{T}}=\mathrm{R}_{\mathrm{V}}+\mathrm{R}_{\mathrm{W}}+\mathrm{R}_{\mathrm{A}}+\mathrm{R}_{\mathrm{APP}}+\mathrm{R}_{\mathrm{SW}}$

$\mathrm{Rv}=\frac{1}{2} \rho \mathrm{S} \mathrm{V}^{2} \mathrm{C}_{\mathrm{v}}$

$\frac{\mathrm{Rw}}{\mathrm{W}}=\mathrm{C}_{1} \mathrm{C}_{2} \mathrm{C}_{3} \mathrm{e}^{\left(\mathrm{m} 1 \mathrm{Fn} \mathrm{d}^{\mathrm{d}}+\mathrm{m} 2 \cos \left(\lambda \mathrm{Fn}^{-2}\right)\right)}$

$\mathrm{R}_{\mathrm{A}}=\frac{1}{2} \rho_{\text {air }} \mathrm{A}_{\mathrm{S}} \mathrm{V}^{2} \mathrm{C}_{\mathrm{A}}$

$\mathrm{EHP}=\mathrm{R}_{\mathrm{T}} \mathrm{V}$

$\eta_{\mathrm{H}}=\frac{\mathrm{EHP}}{\mathrm{THP}}$

$\eta_{\mathrm{p}}=\frac{\text { THP }}{\mathrm{DHP}}$

$\eta_{\text {shaft }}=\frac{\text { DHP }}{\text { SHP }}$

$\eta_{\text {gear }}=\frac{\text { SHP }}{\text { BHP }}$

By determined the break horsepower (BHP), it is the designed power.

The condensate temperature (Ts) and hence the condenser pressure is a function of condenser heat load (Q) and circulating water inlet temperature (Tcwi). The condensate temperature has a linear relationship with the heat load and also cooling water inlet temperature. In practice, the condenser pressure is frequently used instead of condenser temperature. In operation, the condenser temperature (or pressure) cannot be such that the condenser terminal difference is less than $3^{\circ} \mathrm{C}$. If this should occur in calculations, the Heat Exchange Institute recommends that the initial temperature difference equation $\mathrm{Ts}=\mathrm{Tcwo}+3$ be used for an estimate of condenser temperature, as shown in figure (3)

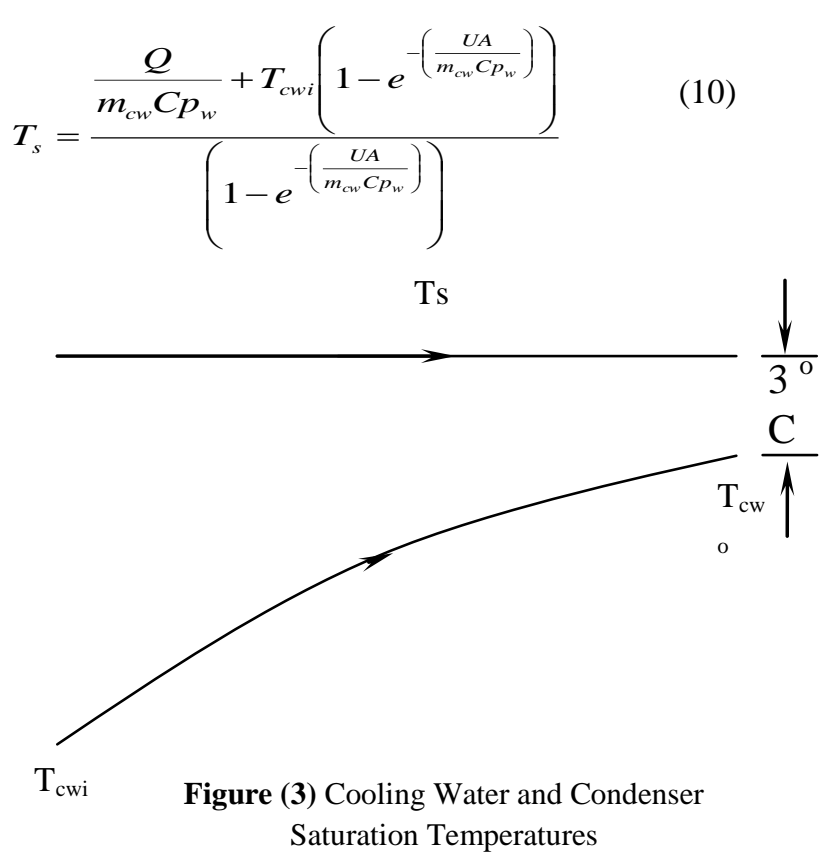

After calculation of ship powering at every case of loading during sailing and determination of the condenser pressure at every cooling water temperature inlet into condenser, now it could be to study the affected parameters combined with changing of cooling water temperture inlet to condenser and boiler pressure, from equations (11) to (15) [14].

$$
\begin{aligned}
& \eta_{\mathrm{th}}=1-\left(\mathrm{h}_{1}-\mathrm{h}_{7}\right) /\left(\mathrm{h}_{3}-\mathrm{h}_{2}\right) \\
& \dot{\mathrm{m}}_{\mathrm{s}}=\mathrm{WT} /\left(\mathrm{h}_{3}-\mathrm{h}_{7}\right) \\
& \text { S.S.C }=3600 /\left(\mathrm{h}_{3}-\mathrm{h}_{7}\right) \\
& \dot{\mathrm{m}}_{\mathrm{f}}=\frac{\dot{m s}(\mathrm{~h} 3-\mathrm{h} 2)}{\eta_{\mathrm{b}} \mathrm{CV}}
\end{aligned}
$$

S.F.C $=\dot{\mathrm{m} f} /$ power

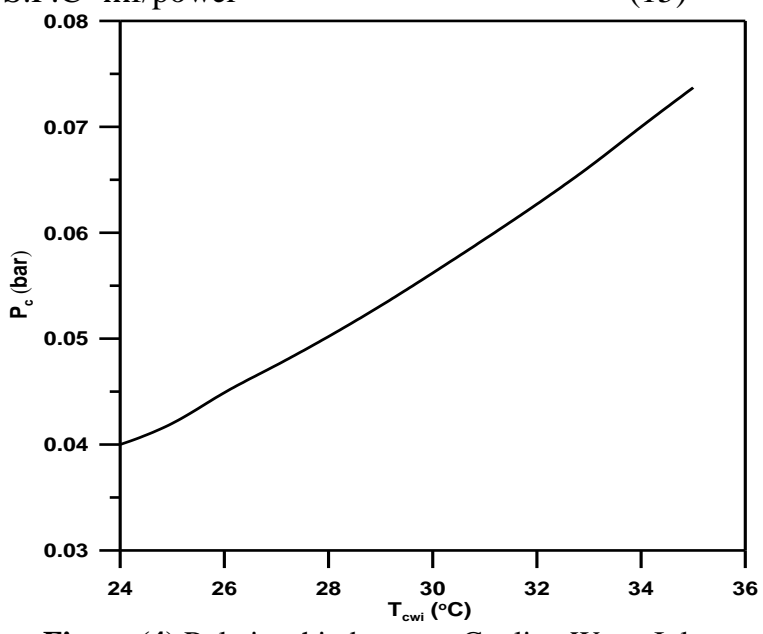

Figure (4) Relationship between Cooling Water Inlet Temperature and Condenser Pressure. 


\subsection{Result and Discussion}

\subsubsection{Ship Resistance and Power Calculations}

\begin{tabular}{|c|c|c|c|}
\hline \multirow{2}{*}{ Parameter } & \multirow{2}{*}{ Equation } & \multicolumn{2}{|c|}{ Values } \\
\cline { 3 - 4 } & & $\begin{array}{c}\text { Full load } \\
\text { condition }\end{array}$ & $\begin{array}{c}\text { Ballast } \\
\text { condition }\end{array}$ \\
\hline $\mathrm{R}_{\mathrm{v}}$ & 2 & $1326 \mathrm{kN}$ & $1207 \mathrm{kN}$ \\
\hline $\mathrm{R}_{\mathrm{w}}$ & 3 & $218.4 \mathrm{kN}$ & $164.3 \mathrm{kN}$ \\
\hline $\mathrm{R}_{\mathrm{A}}$ & 4 & $0.1325 \mathrm{kN}$ & $0.22 \mathrm{kN}$ \\
\hline $\mathrm{R}_{\mathrm{T}}$ & 1 & $1698 \mathrm{kN}$ & $1372 \mathrm{kN}$ \\
\hline EHP & 5 & $17548 \mathrm{~kW}$ & $14174 \mathrm{~kW}$ \\
\hline THP & 6 & $17906 \mathrm{~kW}$ & $14463 \mathrm{~kW}$ \\
\hline DHP & 7 & $28198 \mathrm{~kW}$ & $25599 \mathrm{~kW}$ \\
\hline SHP & 8 & $28773 \mathrm{~kW}$ & $26121 \mathrm{~kW}$ \\
\hline BHP & 9 & $29361 \boldsymbol{k W}$ & $\mathbf{2 6 6 5 4} \boldsymbol{k W}$ \\
\hline
\end{tabular}

\subsubsection{Condenser and Boiler Pressures Effect}

As mentioned above, there is a relationship between the condenser pressure as main study parameter and cooling water temperature inlet to condenser as show in Figure 4. As the inlet temperature to condenser increase from $24^{\circ} \mathrm{C}$ to $35^{\circ} \mathrm{C}$ the condenser pressure increase from 0.04 bar to 0.737 bar.

\subsection{2 .1 Thermal Efficiency}

The overall thermal efficiency of steam cycle is affected by many parameters as boiler pressure, condenser pressure and steam temperature. In fully load condition as shown in Figure 5 and in ballast condition in Figure 11 it was found that the thermal efficiency decreased when the condenser pressure increased at constant boiler pressure and steam temperature. For example at boiler pressure 30 bar and steam temperature $515^{\circ} \mathrm{C}$ the thermal efficiency decreased from $38.5 \%$ to $36.4 \%$ when the condenser pressure increased from 0.04 bar to 0.075 bar and also at all boiler pressure the thermal efficiency decreased when the condenser pressure increased. This condenser pressure based on change the cooling water temperature inlet to condenser. On the other side it was found that the high efficiency was corresponding to the high boiler pressure and lower condenser pressure as the steam temperature was fixed at $515^{\circ} \mathrm{C}$. In Figure 5 or in Figure 11 the best efficiency at high boiler pressure of 60 bar and low condenser pressure of 0.04 bar is $38.5 \%$. By comparison between the two conditions of sailing found that the thermal efficiency was not change in the two conditions because the thermal efficiency depends on the boiler pressure and condenser pressure did not depend on the ship cargo carrying (displacement).

\subsection{2 .2 Fuel Consumption}

If the fuel consumption at any plant is decreased (the main object to economy consideration), it led to save the money paid. It is the best economical solution for any owner to decrease the expenses. In fully load condition in Figure 6 it was found that the fuel consumption increased when the condenser pressure increased at constant boiler pressure and steam temperature of $515^{\circ} \mathrm{C}$ the fuel consumption increased from $2.05 \mathrm{Kg} / \mathrm{s}$ to $2.15 \mathrm{Kg} / \mathrm{s}$ when the condenser pressure increased from 0.04 bar to 0.075 bar at all boiler pressures the fuel consumption increased when the condenser pressure increased led to increase the expenses from 26819 \$/day to 28127 \$/day. It was also found that the lower fuel consumption at high boiler pressure and lower condenser pressure and the higher fuel consumption at low boiler pressure and high condenser pressure with steam temperature fixed at $515{ }^{\circ} \mathrm{C}$. In Figure 6 the lower fuel consumption at boiler pressure 60 bar and condenser pressure at 0.04 bar. In Figure 6 at condenser pressure 0.04 if the boiler pressure increased from 30 bar to $60 \mathrm{bar}$, the fuel consumption decreased by $0.11 \mathrm{Kg} / \mathrm{s}$ it save in day approximately 1439 \$. In ballast condition from Figure 12 it was found that the fuel consumption increased when the condenser pressure increased at constant boiler pressure and steam temperature, for example, at boiler pressure 30 bar and steam temperature $515{ }^{\circ} \mathrm{C}$ the fuel consumption increased from $1.88 \mathrm{Kg} / \mathrm{s}$ to $1.98 \mathrm{Kg} / \mathrm{s}$ when the condenser pressure increased from 0.04 bar to 0.075 bar and the same at all boiler pressures. This condenser pressure based on change the cooling water temperature inlet to condenser, this led to increasing the expenses from 24595 \$/day to 25903 $\$$ /day. It also found also that the lower fuel consumption at high boiler pressure and lower condenser pressure and the higher fuel consumption at low boiler pressure and high condenser pressure with constant steam temperature at $515^{\circ} \mathrm{C}$. In Figure 12 the low fuel consumption at boiler pressure $60 \mathrm{bar}$ and condenser pressure at 0.04 bar, it was also observed that from Figure 12 at condenser pressure 0.04 as the boiler pressure increased from 30 bar to $60 \mathrm{bar}$, the fuel consumption decreased by $0.1 \mathrm{Kg} / \mathrm{s}$ 
led to saving in day approximately 1308 \$.. By comparison between the two conditions of sailing found that the fuel consumption decreased from the fully condition to ballast condition from $1.94 \mathrm{~kg} / \mathrm{s}$ to $1.87 \mathrm{~kg} / \mathrm{s}$ respectively this save approximately 915.8 \$/day to kept the ship speed constant due to that the power is decreased when the cargo weight decreased from $29361 \mathrm{KW}$ to $26654 \mathrm{KW}$.

\subsubsection{Specific Fuel Consumption}

It is a measuring of fuel consumption with respect to power generation by notification of the ratio of fuel consumed used by an engine at a certain force with speed such as the amount of power that the engine produced. Specific fuel consumption compared the engines performance of different sizes to determine which the most efficient fuel consumption is. It allows manufacturers to see which engine will be used for lowest fuel consumption while still producing a high amount of power. From Figures 7 and 13 it was found that the specific fuel consumption increased when the condenser pressure increased at constant boiler pressure and steam temperature. for example at boiler pressure 30 bar and steam temperature $515^{\circ} \mathrm{C}$ the specific fuel consumption is increased from $0.252 \mathrm{Kg} / \mathrm{KW}$ hr to $0.266 \mathrm{Kg} / \mathrm{KW} \mathrm{hr}$ when the condenser pressure increased from 0.04 bar to 0.075 bar, also at all boiler pressure. It was also found that the low specific fuel consumption at high boiler pressure and low condenser pressure because the steam temperature was fixed at $515^{\circ} \mathrm{C}$. In Figures 7 and 13 at boiler pressure 60 bar and condenser pressure 0.04 bar the specific fuel consumption was $0.238 \mathrm{Kg} / \mathrm{kW} \mathrm{hr}$. In two loading conditions during sailing the specific fuel consumption was approximately the same because the lower fuel consumption related to the lower power required for full load and ballast conditions.

\subsubsection{Steam Consumption}

The steam consumption is directly related to the fuel consumption discussed in the previous section, but its importance is related directly to the size of steam plant components which affect the weight of the ships. Its value reflected the amount of steam required in cycle to produce the require work done or useful power. It must be minimum as possible. In fully load condition from Figure 8 it was found that the steam consumption increased when the condenser pressure increased at constant boiler pressure and steam temperature, for example at boiler pressure 30 bar and steam temperature $515^{\circ} \mathrm{C}$, the steam consumption increased from $22.8 \mathrm{Kg} / \mathrm{s}$ to $24.3 \mathrm{Kg} / \mathrm{s}$ when the condenser pressure increased from $0.04 \mathrm{bar}$ to 0.075 bar. It was also found that the lower steam consumption at high boiler pressure and lower condenser pressure while the steam temperature was fixed at $515^{\circ} \mathrm{C}$. In Figure 8, at boiler pressure of 60 bar and condenser pressure of 0.04 bar the steam consumption decreased to $21.7 \mathrm{Kg} / \mathrm{s}$. In ballast condition from Figure 14 it was found that steam consumption increased when the condenser pressure increased at constant boiler pressure and steam temperature, for example at boiler pressure 30 bar and steam temperature $515^{\circ} \mathrm{C}$ the steam consumption increased from $21 \mathrm{Kg} / \mathrm{s}$ to $22.3 \mathrm{Kg} / \mathrm{s}$ when the condenser pressure increased from 0.04 bar to 0.075 bar. It was found also that the lower steam consumption at high boiler pressure and lower condenser pressure because the steam temperature was fixed at $515^{\circ} \mathrm{C}$. In Figure 14 at boiler pressure 60 bar and condenser pressure 0.04 bar the steam consumption is $20 \mathrm{Kg} / \mathrm{s}$. By comparison between the two conditions of sailing found that the steam consumption decreased from fully load condition to ballast load at boiler pressure 60 bar and condenser pressure 0.04 bar from $21.7 \mathrm{~kg} / \mathrm{s}$ to $20 \mathrm{~kg} / \mathrm{s}$ respectively to kept the ship speed constant due to that the power decreased when the cargo weight decreased from $29361 \mathrm{KW}$ to $26654 \mathrm{KW}$.

\subsubsection{Specific Steam Consumption}

It is a criterion of steam plant performance, specific steam consumption relate the power output of a steam plant to the steam flow necessary to produce it. Low values of specific steam consumption mean that the size of a plant and its component parts are smaller than a plant of the same power output, but with a higher specific steam consumption value. In fully loaded in Figure 9 and in ballast condition in Figure 15 it was found that the specific steam consumption increased as the condenser pressure increased at constant boiler pressure and steam temperature, for example at boiler pressure 30 bar and steam temperature $515^{\circ} \mathrm{C}$ the specific steam consumption increased from $2.79 \mathrm{Kg} / \mathrm{kW}$ hr to $2.99 \mathrm{Kg} / \mathrm{kW} \mathrm{hr}$ and hence if the condenser pressure increased from 0.04 bar to 0.075 bar at all boiler pressure, the specific steam consumption increased when the condenser pressure increased. It was also found that the low specific steam at high boiler pressure and low condenser pressure with steam temperature fixed at $515^{\circ} \mathrm{C}$. In Figures 9 and 15 at boiler pressure 60 bar and condenser pressure 0.04 bar the specific steam consumption is $2.68 \mathrm{Kg} / \mathrm{kW} \mathrm{h}$. 


\subsubsection{Cooling Water Mass Flow Rate}

The condenser-cooling-water temperature rise and mass-flow rate are related to the rejected heat load. The cooling water inlet to condenser from the sea inside the tubes to absorb heat from the steam is very important in calculations because it directly related to the pressure drop and condenser sizing, the mass flow rate and pressure drop are the main parameters for pumping system performance. In Figure 10 found that the cooling water mass flow rate increased when the condenser pressure increased at constant boiler pressure and steam temperature. It could be observed for example at boiler pressure 30 bar and steam temperature $515^{\circ} \mathrm{C}$ that the cooling water mass flow rate is increase from $1120 \mathrm{~kg} / \mathrm{s}$ to $1220 \mathrm{~kg} / \mathrm{s}$ lead to high pumping power when the condenser pressure increase from 0.04 bar to 0.075 bar for all boiler pressure are the same as the cooling water mass flow rate increased when the condenser pressure increased. It was also found that the low cooling water mass flow rate at high boiler pressure and low condenser pressure as the steam temperature was fixed at $515^{\circ} \mathrm{C}$. In Figure 10 at boiler pressure of 60 bar and condenser pressure of 0.04 bar the cooling water mass flow rate is $1018 \mathrm{~kg} / \mathrm{s}$.

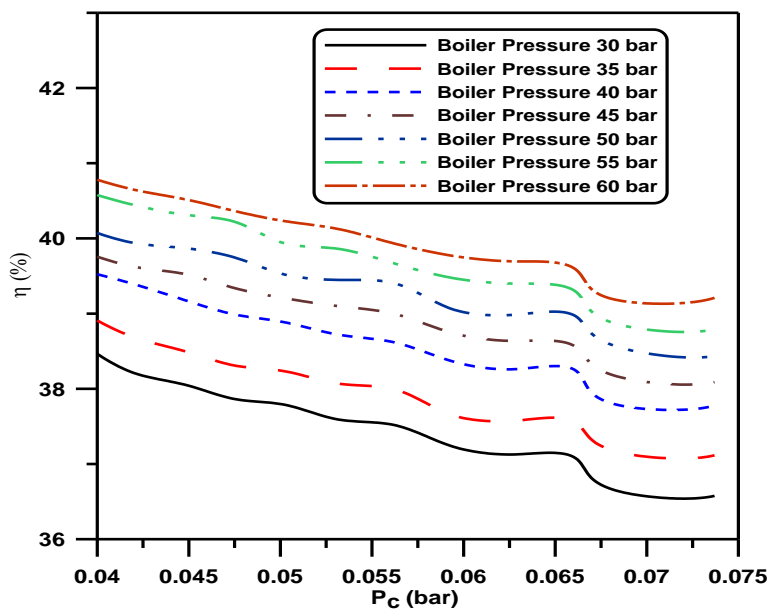

Figure (5): Condenser and Boiler Pressures Effect on Thermal Efficiency (Full Load Conditions)

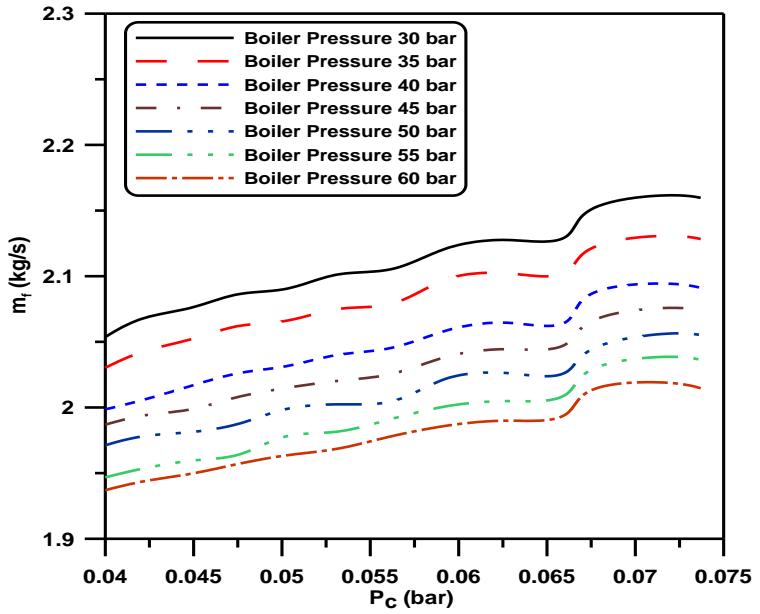

Figure (6) Condenser and Boiler Pressures Effect on Fuel Consumption (Full Load Conditions)

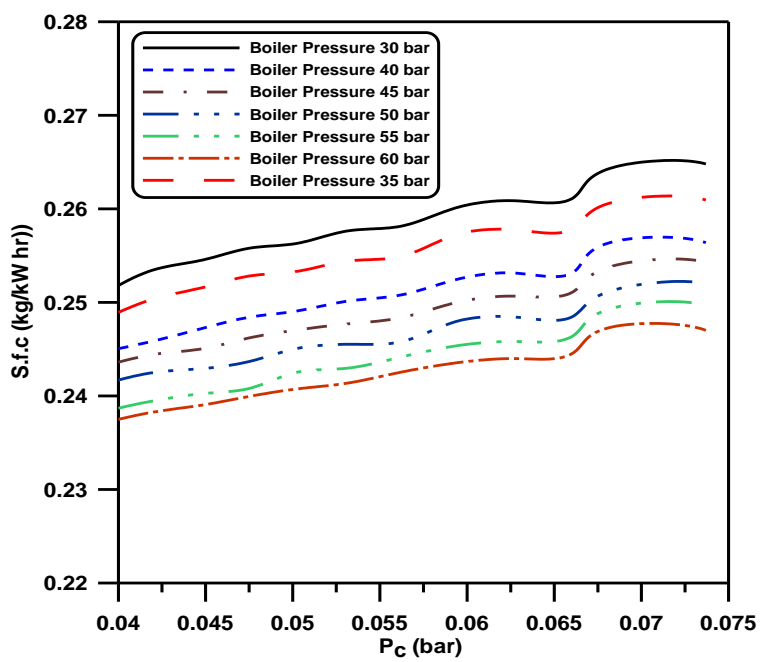

Figure (7): Condenser and Boiler Pressures Effect on Specific Fuel Consumption (Full Load Conditions)

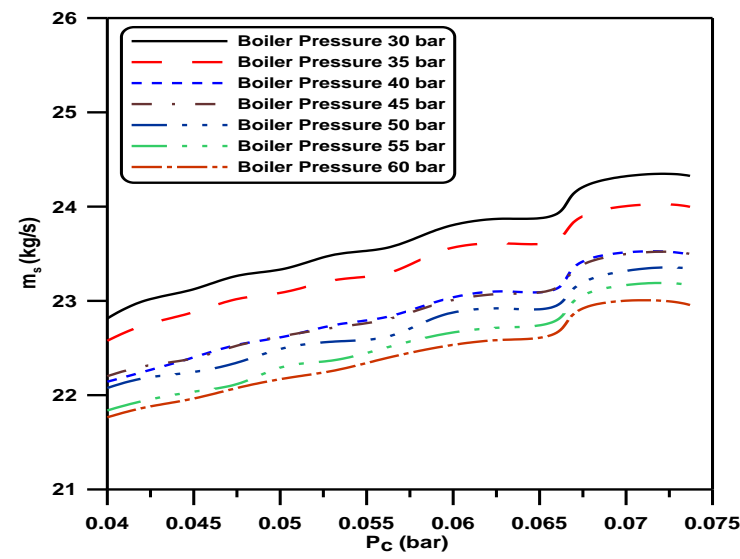

Figure (8) Condenser and Boiler Pressures Effect on Steam Consumption (Full Load Conditions) 


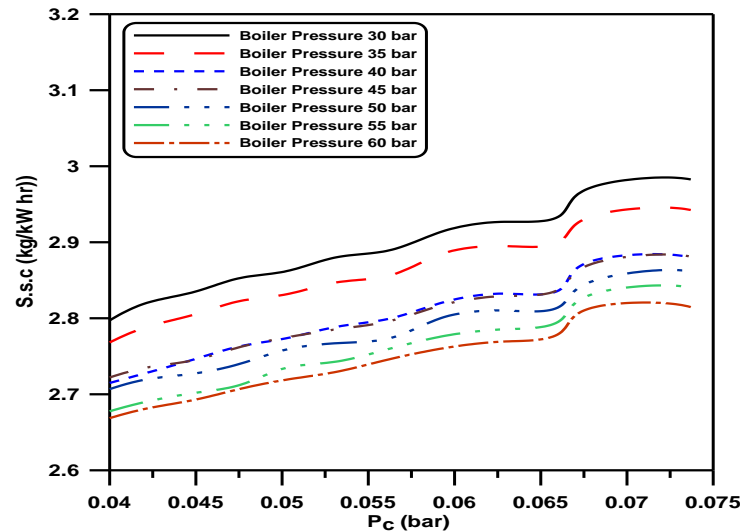

Figure (9) Condenser and Boiler Pressures Effect on Specific Steam Consumption (Full Load Conditions)

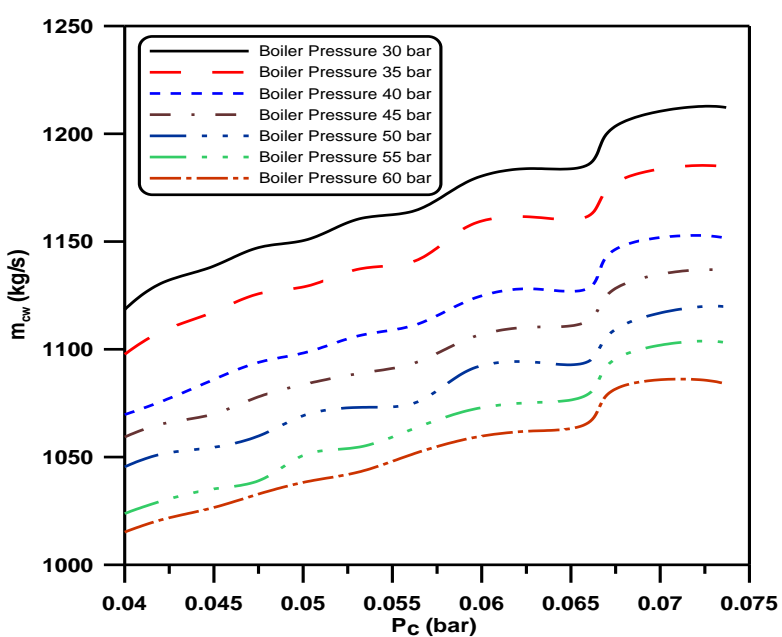

Figure(10) Condenser and Boiler Pressures Effect on Cooling Water Mass Flow Rate (Full Load Conditions)

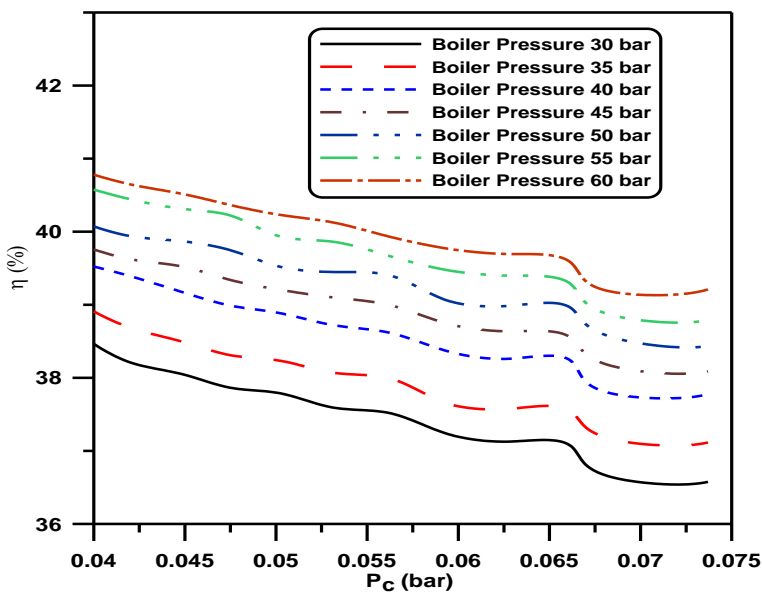

Figure (11) Condenser and Boiler Pressures Effect on Thermal Efficiency (Ballast Conditions)

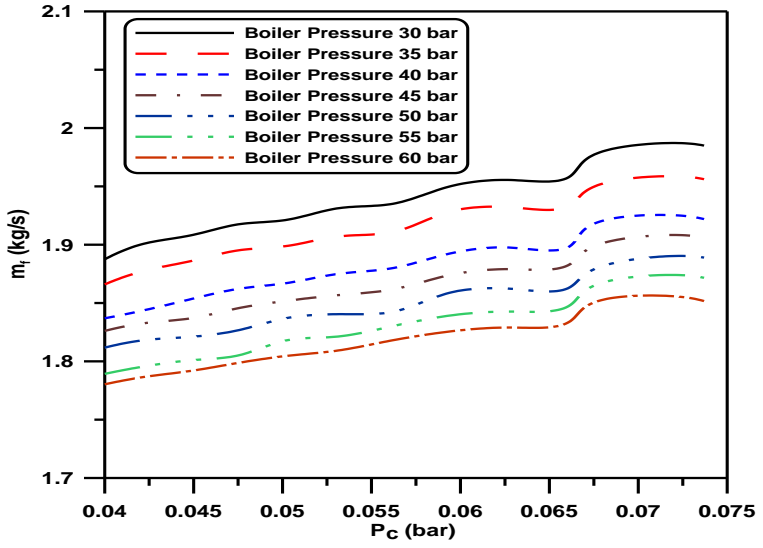

Figure (12) Condenser and Boiler Pressures Effect on Fuel Consumption (Full Load Conditions)

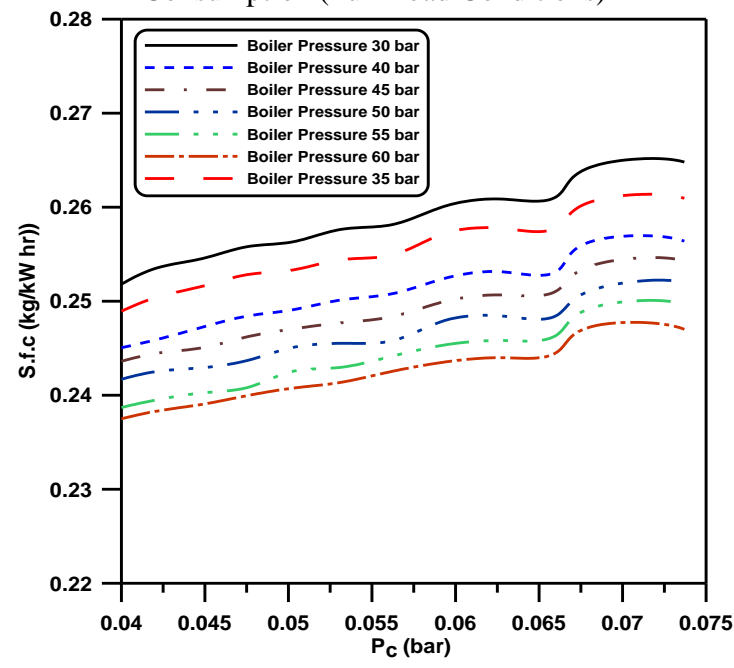

Figure (13) Condenser, Boiler Pressures Effect on Specific Fuel Consumption (Ballast Condition)

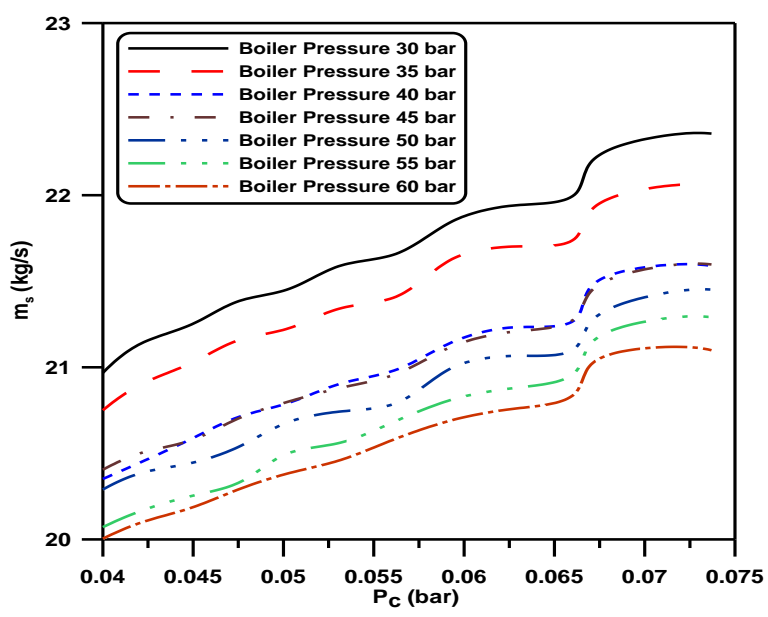

Figure (14) Condenser and Boiler Pressures Effect on Steam Consumption (Ballast Condition) 


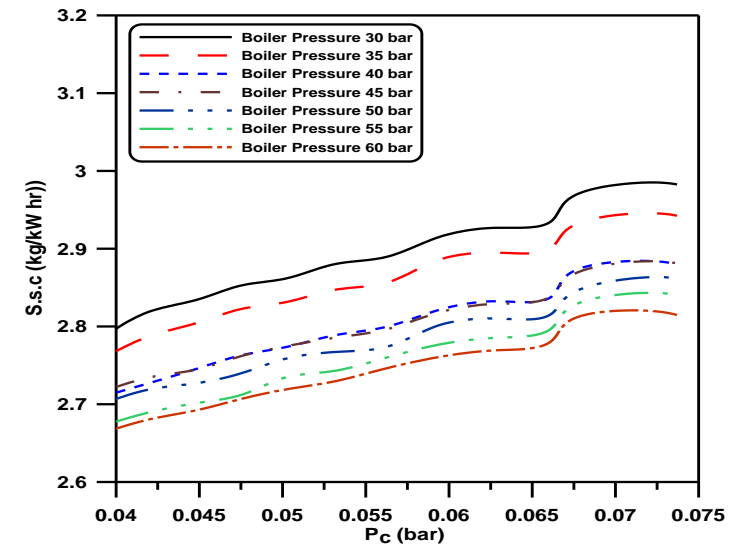

Figure (15) Condenser and Boiler Pressures Effect on Specific Steam Consumption (Ballast Condition)

\section{CONCLUSIONS}

From the study it was found that

- As the cooling water temperature inlet to condenser decreased, the pressure is decreased, and vice versa.

- There is an inverse relationship between the thermal efficiency and the cooling water temperature inlet to condenser.

- There is a proportionalrelationship between the thermal efficiency and theboiler pressure.

- The specific fuel consumption has proportional relationship with cooling water temperature inlet to condenser, where it has an inverse relationship with the boiler pressure.

- Also, there is a proportional relationship between the fuel consumption and sailing loading condition.

- The specific steam consumption has proportional relationship with cooling water temperature inlet to condenser, where it has an inverse relationship with the boiler pressure.

- There is a proportional relationship between the steam consumption and sailing loading condition.

- Finally, the mass flow rate of cooling water inlet to condenser has a proportional relationship with its temperature, where it has an inverse relationship with the boiler pressure.

\section{REFERENCES}

[1] D. A. Taylor, "Introduction to marine engineering", Elsevier Butterworth Hbnemann, 1996.

[2] Dongil Yeo, Byungsam, Jinmo Kim, Ilyong Kim and Samsung Heavy Industries Co., Ltd, " Propulsion alternatives for modern LNG carriers ", 2005.

[3] James Gaughan, "Economics, environment driving new generation of LNG carrier", 2007.

[4] R M Pitblado, J Baik, G J Hughes, C Ferro and S J Shaw, "Consequences of LNG Marine Incidents", CCPS Conference Orlando, 2004.

[5] Makoto Ito, Kazuyoshi Hiraoka, Shoichi Matsumoto and Kenji Tsumura, "Development of high Efficiency Marine Propulsion Plant (Ultra Steam Turbine) ", 2007.

[6] J. T. Holm, "Marine steam power plant heat balance practices ", 1980 .

[7] George G. Dimopoulos and Christos A. Frangopoulos, "Thermo economic Simulation of Marine Energy Systems for a Liquefied Natural Gas Carrier", 2008.

[8] Kawasaki URA turbine catalogue, 2001.

[9] Kawasaki UM boiler catalogue, 2001.

[10] Kawasaki UA turbine catalogue, 2001.

[11] Volker Bertram, "Practical ship hydrodynamic", ButterworthHeinemann, 2000.

[12] K.J.Rawson and E.C.Tupper, "Basic ship theory", Butterworth-Heinemann, 2001

[13]E.C. Tupper, "Introduction of naval architecture", Butterworth-Heinemann, 2004.

[14] Yunus A. Cengel and Michael A. Boles, "Thermodynamic", McGraw-Hill Professional, 2001. 


\section{NOMENCLATURE}

\section{Symbols}

$\mathrm{A}_{\mathrm{s}} \quad$ projected area to wind, $\mathrm{m}^{2}$

BHP Break power, $\mathrm{kW}$

$\mathrm{C}_{1} \quad$ Coefficient depend on hull form

$\mathrm{C}_{2} \quad$ Coefficient depend on shape of bow

$\mathrm{C}_{3} \quad$ Coefficient depend on shape of stern

$\mathrm{C}_{\mathrm{A}} \quad$ Air resistance coefficient

$\mathrm{C}_{\mathrm{f}} \quad$ Frictional resistance coefficient

$\mathrm{C}_{\mathrm{pw}} \quad$ Specific heat of water, $\mathrm{kJ} / \mathrm{kg}{ }^{\circ} \mathrm{C}$

$\mathrm{C}_{\mathrm{v}} \quad$ Viscous resistance coefficient

$\mathrm{CV}$ Colorific value of fuel, $\mathrm{kJ} / \mathrm{kg}$

DHP Delivered power, $\mathrm{kW}$

EHP Effective power, $\mathrm{kW}$

$\mathrm{F}_{\mathrm{n}} \quad$ Froude number

$\mathrm{h}_{1} \quad$ Enthalpy at exit of condenser, $\mathrm{kJ} / \mathrm{kg}$

$\mathrm{h}_{2} \quad$ Enthalpy at inlet to boiler, $\mathrm{kJ} / \mathrm{kg}$

$\mathrm{h}_{3} \quad$ Enthalpy at inlet to HP turbine, $\mathrm{kJ} / \mathrm{kg}$

$\mathrm{h}_{6} \quad$ Enthalpy at exit of HP turbine, $\mathrm{kJ} / \mathrm{kg}$

$\mathrm{h}_{7} \quad$ Enthalpy at inlet of LP turbine, $\mathrm{kJ} / \mathrm{kg}$

$\mathrm{m}_{1} \quad$ Coefficient depend on hull form

$\mathrm{m}_{2} \quad$ Coefficient depend on hull form

$\dot{\mathrm{m}}_{\mathrm{cw}} \quad$ Cooling water mass flow rate

$\dot{\mathrm{m}}_{\mathrm{f}} \quad$ Fuel consumption, $\mathrm{kg} / \mathrm{s}$

$\dot{\mathrm{m}}_{\mathrm{s}} \quad$ Steam mass flow rate, $\mathrm{Kg} / \mathrm{s}$

$\mathrm{P}_{\mathrm{c}} \quad$ condenser pressure, bar

Power steam station power (BHP), $\mathrm{kW}$

$\mathrm{Q}_{\mathrm{add}} \quad$ Heat added to the system, $\mathrm{kW}$

$\mathrm{R}_{\mathrm{A}} \quad$ Air resistance, $\mathrm{kN}$

$\mathrm{R}_{\text {app }} \quad$ Appendage resistance, $\mathrm{kN}$

$\mathrm{R}_{\mathrm{sw}} \quad$ Sea wave resistance, $\mathrm{kN}$

$\mathrm{R}_{\mathrm{T}} \quad$ Total ship resistance, $\mathrm{kN}$

$\mathrm{R}_{\mathrm{V}} \quad$ Viscous resistance, $\mathrm{kN}$

$\mathrm{R}_{\mathrm{w}} \quad$ Wave making resistance, $\mathrm{kN}$

$\mathrm{S} \quad$ Wetted surface area, $\mathrm{m}^{2}$

SHP Shaft power, $\mathrm{kW}$

$\mathrm{T}_{\text {cwi }} \quad$ Cooling water inlet temperature, ${ }^{\circ} \mathrm{C}$

$\mathrm{T}_{\mathrm{cwo}} \quad$ Cooling water outlet temperature, ${ }^{\circ} \mathrm{C}$

$\mathrm{T}_{\mathrm{s}} \quad$ Saturated temperature, ${ }^{\circ} \mathrm{C}$

THP Thrust power, $\mathrm{kW}$

$\mathrm{U} \quad$ Heat transfer coefficient, $\mathrm{W} / \mathrm{m}^{2} \mathrm{C}$

$\mathrm{V} \quad$ Ship speed, $\mathrm{m} / \mathrm{s}$

$\mathrm{W}_{\mathrm{T}} \quad$ Turbine work done, $\mathrm{kW}$

\section{Greek symbols}

$\begin{array}{ll}\eta_{\mathrm{b}} & \text { Boiler efficiency } \\ \eta_{\mathrm{H}} & \text { Hull efficiency } \\ \eta_{\text {gear }} & \text { Reduction gear efficiency } \\ \eta_{\mathrm{p}} & \text { Propeller efficiency } \\ \eta_{\text {shaft }} & \text { Shaft efficiency } \\ \eta_{\mathrm{th}} & \text { Thermal efficiency } \\ \lambda & \text { Coefficient depend on hull form } \\ \rho & \text { Density of sea water, ton } / \mathrm{m}^{3} \\ \rho_{\text {air }} & \text { Air density, ton } / \mathrm{m}^{3}\end{array}$

\section{List of abbreviations}

BOG Boil of Gas

CST Conventional Steam Turbine

FPP Fixed pitch propeller

LNG Liquefied Natural Gas

SFC Specific Fuel Consumption

SSC Specific Steam Consumption

UST Ultra Steam Turbine

VLCC Very Large Crude Carrier 